УДК 811.111'37:621

DOI https://doi.org/10.26661/2414-9594-2021-1-17

\title{
ОМОНІМІЯ В СУЧАСНІЙ АНГЛІЙСЬКІЙ ТЕРМІНОЛОГІЧНІЙ ПІДСИСТЕМІ НАСОСОБУДУВАННЯ
}

\author{
Литвинко О. А. \\ кандидат філологічних наук, дочент, \\ доцент кафедри іноземних мов \\ Сумський наиіональний аграрний університет \\ вул. Герасима Кондратьєва, 160, Суми, Украӥна \\ orcid.org/0000-0002-2241-3776 \\ oxana.litvinko@gmail.com
}

\begin{abstract}
Ключові слова:
термінологічна підсистема, насособудування, термін, омонімія, омонім, міждисциплінарний омонім, омонімічне скорочення, внутрішньогалузева омонімія, професійна комунікащія.
\end{abstract}

Стаття присвячена вивченню феномену омонімії в сучасній англійській термінологічній підсистемі насособудування. Наявність омонімії в терміносистемах різних галузей $є$ очевидною. Лексичні одиниці термінологічної підсистеми насособудування відповідають основним вимогам, що висуваються до термінів. Проте термінологія зазначеної підсистеми не позбавлена омонімічних відношень.

Виникнення омонімії в термінологічній підсистемі насособудування пояснюється процесами дивергенції та конвергенції лексичних одиниць, а також запозиченнями $з$ інших мов.

Омонімами вважаємо слова, які мають спільне звучання, але семантизують різні поняття.

Серед омонімів, що функціонують у термінологічній підсистемі насособудування, виокремлюються загальнотехнічні терміни, що вживаються в суміжних галузях науки і техніки, терміни-омоніми, що функціонують у несуміжних галузях науки і техніки, та терміни-омоніми, що властиві лише субмові насособудування.

Міждисциплінарні терміни-омоніми піддалися переосмисленню i ввійшли в терміносистему іншої наукової сфери. Нами було виявлено, що за такими термінами закріплені різні дефініції, ці терміни функціонують у суміжних і несуміжних термінологічних підсистемах. До міждисциплінарних омонімів відносять відповідні скорочені одиниці. Внутрішньогалузевій омонімії властива та сама форма слова, що має різні значення в межах згаданої технічної галузі.

Аналіз субмови насособудування свідчить, що міждисциплінарні омоніми не мають ні негативних, ні позитивних рис. Міждисциплінарні омонімічні скорочення зручні для користування з огляду на їхню форму, але вони спричиняють непорозуміння між фахівцями. Терміни-омоніми, що властиві лише галузі насособудування, ускладнюють професійну комунікацію.

Теоретичне значення пропонованого дослідження визначається його внеском у загальну теорію терміна і термінологію. Результати дослідження доповнюють наукові знання про особливості термінологічної номінації та основні тенденції термінотворення в сучасній англійській термінологічній підсистемі насособудування. 


\title{
HOMONYMY IN MODERN ENGLISH PUMP ENGINEERING TERMINOLOGICAL SUBSYSTEM
}

\author{
Lytvynko O. A. \\ Ph. D. in Philology, Associate Professor, \\ Associate Professor at Foreign Languages Department \\ Sumy National Agrarian University \\ Herasima Kondratieva str., 160, Sumy, Ukraine \\ orcid.org/0000-0002-2241-3776 \\ oxana.litvinko@gmail.com
}

Key words: terminological subsystem, pump engineering, term, homonymy, homonym, interdisciplinary homonymy, abbreviated unit, intra-industry homonymy, professional communication.
This article focuses on the problem of homonymy in modern English terminology within the special subsystem of terms - pump engineering. The presence of homonymy in terminology is obvious. Lexical units of the terminological subsystem of pump engineering meet the basic requirements for terms. However, the terminology of this subsystem is not devoid of homonymous relations.

The appearance of homonymy in the terminological subsystem of pump engineering is explained by the processes of divergence and convergence of lexical units, as well as borrowings from other languages.

We consider homonyms to be words that are said the same but semantize different concepts.

Homonyms functioning in the terminological subsystem of pump engineering are classified into general technical terms used in related fields of science and technology, homonymous terms functioning in non-related fields of science and technology and homonymous terms that are peculiar only to pump engineering subsystem.

Interdisciplinary homonymous terms have been reconsidered and entered the terminology of another scientific field. Such terms have different definitions and function in related and non-related terminological subsystems. Interdisciplinary homonyms include the corresponding abbreviated units.

Intra-industry homonymy is characterized by the same form of the word, which has different meanings within this technical field.

The analysis of the pump engineering sublanguage shows that interdisciplinary homonyms have neither negative nor positive features. Interdisciplinary homonymous abbreviations are convenient to use due to their form, but they contribute to misunderstandings between professionals. Homonyms that are specific to the pump engineering industry complicate professional communication. The theoretical significance of this study is determined by its contribution to the general theory of the term and terminology. The results of the research complement the scientific knowledge about the peculiarities of the terminological nomination and the main tendencies of term formation in the modern English terminological subsystem of pump engineering.
Постановка проблеми. Одним 3 актуальних завдань сучасної лінгвістики є вивчення терміносистем у межах конкретної сфери людської діяльності. Нині накопичений багатий матеріал 3 аналізу термінологій і термінологічних систем, що мають тривалий період становлення або виникли нещодавно. Особливу увагу науковці фокусують на систематизації й удосконаленні терміносистем окремих галузей, оскільки саме в науковій мові різних галузей активно породжуються нові та переосмислюються старі поняття, найбільш яскраво реалізуються міжмовні контакти і живі процеси формування термінів.

Інтерес лінгвістів до омонімії корелює безпосередньо з потребою виявлення особливостей розгляданого мовного процесу, з'ясування причин появи омонімів, визначення чітких критеріїв розмежування омонімії та полісеміі. У сучасній лінгвістиці вдосконалюються наукові підходи до вивчення омонімії на матеріалі різних термінологічних 
підсистем, виявляються диференційні ознаки цих лексичних одиниць. Проте, незважаючи на значні досягнення в дослідженні проблеми омонімії в сучасній лінгвістиці (М. Кочерган [1], О. Суперанська, Н. Подольська, Н. Васильєва [2], Ю. Грибіник [3], Я. Тагільцева [4], В. Фідик [5] та інші), немає єдиного загальноприйнятого визначення $\mathrm{i}$ розуміння цього явища.

Актуальність дпропонованої статті зумовлена відсутністю спеціальних грунтовних досліджень термінології субмови насособудування, бурхливим розвитком згаданої технічної галузі на сучасному етапі та необхідністю уніфікації й удосконалення іiі термінології. У зазначеній термінологічній підсистемі омоніми представлені у великій кількості, а це вимагає створення особливого наукового підходу до цього феномену.

Матеріалом дослідження слугував корпус термінологічної лексики обсягом 5000 лексичних одиниць, відібраних методом суцільної вибірки 3 лексикографічних джерел (тлумачні словники термінів насособудування; перекладні словники термінів насособудування), 3 рекламних проспектів фірм - виробників продукції насособудування та 3 періодичних видань у галузі насособудування. Загальний обсяг опрацьованого матеріалу - приблизно 9500 сторінок тексту.

Метою статті є вивчення специфіки феномену омонімії в сучасній англійській термінологічній підсистемі насособудування, виокремлення типів термінологічних омонімів.

Виклад основного матеріалу дослідження. Явище омонімії спостерігається як в загальній, так і у спеціальній лексиці. Омонімами вважаємо слова, що мають спільне звучання, але семантизують різні поняття [2, с. 45; 5, с. 268]. У лінгвістиці існує думка про те, що зазначені лексичні одиниці не тільки не мають спільних сем, а й не пов'язані асоціативно [1, с. 198].

Виникнення омонімів у мові зумовлено різними причинами. По-перше, вони могли з'явитися як результат історичних фонетичних змін, коли на певному етапі відбувся збіг слів, які раніше були різними за вимовою. По-друге, ці лексичні одиниці могли виникнути завдяки семантичному зсуву за суміжністю (метонімічне перенесення) [2, с. 45].

Омонімія може також виникнути завдяки процесам метафоризації. Слово англійської загальної мови arm у значенні «рука від кисті до плеча» шляхом метафоричного перенесення термінологізувалося в $\mathrm{arm}$ («плече (важеля)») субмови насособудування. Але в такому разі мають рацію науковці, які зауважують, що лексичні одиниці не можна вважати омонімічними, доки відчувається метафора. Коли ж вона поступово зникає, а вживання в новому значенні стає регулярним - це омонімія [2, с. 45].
Виникнення омонімії в термінологічній підсистемі зумовлено процесами дивергенції та конвергенції лексичних одиниць, а також запозиченнями з інших мов [5, с. 269].

До феномену омонімії в термінології лінгвісти ставляться по-різному. Деякі вчені визнають небажаність цього явища. Зокрема, А. Реформатський зазначав, що коли багатозначність - законне явище мови, то омонімія - «незаконна», але постійно може спостерігатися. М. Кочерган зауважує, що омоніми іноді призводять до непорозуміння. Саме на цій їхній властивості будуються каламбури (гра слів) і анекдоти [1, с. 201]. Інші вчені не визнають негативних якостей омонімів і вважають їхній вплив нейтральним. А. Суперанська, Н. Подольська та Н. Васильєва зосереджують увагу на тому, що омонімічні одиниці корелюють із різними семантичними полями, це перешкоджає їхньому зіткненню в суміжних контекстах [2, с. 46]. Омоніми, які належать до суміжних технічних галузей, не заважають професійній комунікації.

У сучасній лінгвістиці існує проблема розмежування омонімів і полісемічних лексичних одиниць, оскільки межі між полісемічним і омонімічним словом вельми умовні. Більшість дослідників наголошують на тому, що омоніми варто дистантувати від полісемічних слів. Так, М. Кочерган зазначає, що в разі багатозначності одне слово має декілька корелюючих значень, а в разі омонімії маємо декілька слів, значення яких не мають спільних сем i асоціативних зв'язків [1, с. 198]. Для вирішення проблеми чіткої диференціації полісемічних і омонімічних лексичних одиниць було запропоновано етимологічний критерій [3, с. 193]. Отже, омонімами варто вважати лише слова, що різняться за своєю етимологією. Але реалізація цього підходу ускладнюється тим, що не завжди є можливість знайти походження слова. Об'єктивним критерієм омонімії іноді вважається відмінність у складі граматичних категорій для двох лексичних значень [3, с. 183]. Доцільно зауважити, що етимологічний i граматичний аналіз дозволяють виявити семантичний інваріант досліджуваних слів, що є результатом полісеміі, а не омонімії. Актуалізація понятійних зв'язків терміна завуальовує предметну співвіднесеність терміна з об'єктивною дійсністю. Тому необхідно розкривати зв'язки слова, аналізувати його семантичну організацію для розмежування полісемії й омонімії.

Опозиційним $є$ підхід, коли явище полісемії визнається тотожним омонімії, тобто існування багатозначних термінів піддається сумніву. Зазначається, що недоцільно вважати, ніби слова мають декілька значень, насправді ми маємо стільки слів, скільки фонетичне слово має значень [6, с. 81]. Але варто зауважити, що значення слів-омонімів завжди взаємовиключні. 
Водночас між значеннями багатозначних слів існують відношення односпрямованої детермінації (коли одне значення припускає інше) або невзаємовиключної диз'юнкції (коли реалізація одного зі значень залежить від лексико-синтаксичної позиції слова, але між такими значеннями не має непереборного кордону; існують такі позиції слова, у яких відмінні в інших випадках значення виявляються спорідненими, сумісними) [6, с. 90].

У сучасній лінгвістиці існує декілька підходів до класифікації омонімів. Деякі лінгвісти пропонують розмежовувати омофони, омоформи, омографи і граматичні омоніми [7, с. 37].

M. Кочерган наголошує на тому, що омоформи й омографи варто вважати суміжними з омонімією явищами. Він пропонує класифікувати омоніми за формою і за походженням. На думку дослідника, за формою потрібно розрізняти повні та неповні омонімічні одиниці. Повні омоніми мають абсолютний збіг форм у разі їх змінювання, неповні омоніми збігаються не в усіх формах. За походженням учений виокремлює гомогенні і гетерогенні одиниці. Гомогенні (від гр. homohenes - oднорidний) омоніми дослідник розуміє як омонімічні одиниці, що виникли внаслідок розпаду одного слова на два. Такий розпад зумовлений втратою (розривом) зв'язків між окремими значеннями вихідного багатозначного слова. Гетерогенні омоніми (від гр. heterogenes - неоднорідний) виникли внаслідок збігу етимологічно різних слів [1, с. 199].

Крім внутрішньослівної омонімії, дослідник виокремлює і міжмовну. До міжмовних омонімів науковець відносить слова різних мов, що мають однакову чи майже однакову форму, але різняться за значенням. Міжмовні омоніми ще називають «фальшивими друзями перекладача», бо спеціаліст, який довірився звучанню слова, може припуститися грубої помилки [1, с. 201]. А. Суперанська, Н. Подольська та Н. Васильєва заперечують існування міжмовних омонімів, як і синонімів, з огляду на те, що багато речей називаються в різних мовах по-різному, але люди, що користуються однією мовою, цього просто не помічають [2, с. 46$]$.

А. Сухова й І. Степанішина виокремлюють міжгалузеву та внутрішньогалузеву омонімію в науково-технічних терміносистемах [8, с. 232].

Феномен омонімії репрезентується в терміносистемах різних галузей науки і техніки. Лексичні одиниці термінологічної підсистеми насособудування відповідають основним вимогам, що висуваються до термінів. Проте термінологія насособудування не позбавлена омонімічних відношень. Омонімічні одиниці, що входять до складу зазначеної галузі, можна класифікувати так.

1. Міждисциплінарні терміни-омоніми, що вживаються в суміжних галузях науки і техніки, які пов'язані спільними технологічними проце- сами та безпосередніми виробничими зв'язками. До комплексу суміжних із насособудуванням галузей відносять машинобудування й автоматизацію виробництва. Пор.:

- item:

1) «виріб», «одиниця обладнання» (субмова насособудування);

2) «елемент даних» (субмова автоматизації виробництва);

- hood:

1) «кожух» (субмова машинобудування);

2) «ковпак» (субмова насособудування).

2. Міждисциплінарні терміни-омоніми, що функціонують у несуміжних галузях науки і техніки. Такі терміни різняться дефініціями і належать до несуміжних науково-технічних підсистем. Пор.:

- collector:

1) «колектор електромашини» (субмова насособудування);

2) «колектор» (субмова сільського господарства);

3) «ділянка сіті, що збирає стічні води» (субмова будівництва);

- chute:

1) «жолоб» (субмова насособудування);

2) «парашут» (субмова авіації);

3) «люк» (субмова гірничої справи).

Серед міждисциплінарних омонімів виокремлюються скорочені одиниці. Пор.:

- DC:

1) direct current - «постійний струм» (субмова насособудування, машинобудування);

2) distance between centers - «дистанція між иентрами» (математика, матинобудування, насособудування); mвo).

3) double column - «двоколонний» (будівниц-

3. Терміни-омоніми, що властиві лише галузі насособудування. Для внутрішньогалузевої омонімії характерна та сама форма слова, що має різні значення в межах певної галузі науки або техніки.

Пор.:

- dolly (транспортний візок) - dolly (полірувальний круг);

- gear (зубчаста передача) - gear (привод);

- тиffle (блок з багатьма шківами) - тиffle (глушник).

Висновки. Аналіз сучасної англійської термінологічної підсистеми насособудування свідчить, що міждисциплінарні омоніми не мають ні негативних, ні позитивних рис. Міждисциплінарні омонімічні скорочення зручні для користування 3 огляду на їхню форму, але вони сприяють непорозумінню між спеціалістами. Терміни-омоніми, що властиві лише галузі насособудування, теж ускладнюють комунікацію фахівців. 
Виникнення омонімії в термінологічній підсистемі зумовлено процесами дивергенції та конвергенції лексичних одиниць, а також запозиченнями 3 інших мов. Незважаючи на те, що омоніми спричиняють непорозуміння між спеціалістами, вони функціонують у мовленні фахівців, бо їх важко позбутися. Зазначені лексичні одиниці можуть поступово зникнути у процесі вдосконалення термінологічної підсистеми. Правильному тлумаченню таких термінів зазвичай допомагає контекст.

У перспективі передбачається дослідити процеси детермінологізації на матеріалі сучасної англійської термінологічної підсистеми насособудування.

\section{ЛІТЕРАТУРА}

1. Кочерган М. Вступ до мовознавства. Київ : Академія, 2010. 367 с.

2. Суперанская А., Подольская Н., Васильева Н. Общая терминология. Вопросы теории. Москва : Либроком, 2012. 243 с.

3. Грибіник Ю. Явища полісемії та омонімії в англійській геодезичній термінології. Молодий вчений. 2015. Вип. 2 (1). С. 191-194.

4. Тагільцева Я. Термінологічна омонімія в номінаціях овочів та фруктів сучасної англійської мови. Філологічні науки. 2013. Вип. 15. С. 82-87.

5. Фідик В. Омонімна лексика в англійському фольклорі: структурно-семантичний аспект. Молодий вчений. 2017. Вип. 4 (3). С. 268-271.

6. Шмелев Д. Современный русский язык. Лексика. Москва : Либроком, 2017. 336 с.

7. Дутка О. Омонімія в колі сучасних наукових проблем. Сучасні проблеми мовознавства та літературознавства. 2014. Вип. 19. С. 36-40.

8. Сухова А., Степанішина I. Міжгалузева та внутрішньогалузева омонімія науково-технічних термінів та труднощі їх перекладу. Проблеми та перспективи формування нащіональної гуманітарно-технічної еліти. Харків. 2011. Вип. 29 (33). С. 232-238.

\section{REFERENCES}

1. Kochergan M.P. (2010) Vstup do movoznavstva [Introduction into Linguistics] - Kyiv: Akademiya. 367 p.

2. Superanskaya A.V., Podolskaya, N.V. \& Vasilieva N.V. (2012) Obschaya terminologiya. Voprosy teorii. [General terminology. Questions of theory] - M.: Librokom. 243 p.

3. Hrybinyk Y.I. (2015) Yavyshcha polisemii ta omonimii v anhliiskii heodezychnii terminolohii [Phenomena of polysemy and homonymy in English geodetic terminology] Molodyi vchenyi. Vol. 2 (1). P. 191-194.

4. Tagiltseva J. (2013) Terminolohichna omonimiia v nominatsiiakh ovochiv ta fruktiv suchasnoi anhliiskoi movy [Terminological homonymy in the nominations of vegetables and fruits of modern English] Filolohichni nauky. Vol. 15. P. 82-87.

5. Fidyk V. (2017) Omonimna leksyka v anhliiskomu folklori: strukturno-semantychnyi aspect [Homonymous vocabulary in English folklore: structural and semantic aspect] Molodyi vchenyi. Vol. 4 (3). P. 268-271.

6. Shmelev D.N. (2017) Sovremennyiy russkiy yazyik. Leksika. [Modern Russian language. Vocabulary] M.: Librokom. 336 p.

7. Dutka O. (2014) Omonimiia v koli suchasnykh naukovykh problem. [Homonymy in the circle of modern scientific problems] Suchasni problemy movoznavstva ta literaturoznavstva. Vol. 19. P. 36-40.

8. Sukhova A.V., Stepanishina I.S. (2011) Mizhhaluzeva ta vnutrishnohaluzeva amonimiia naukovotekhnichnykh terminiv ta trudnoshchi yikh perekladu [Intersectoral and intra-industry amonymy of scientific and technical terms and difficulties of their translation] Problemy ta perspektyvy formuvannia natsionalnoi humanitarno-tekhnichnoi elity. - Kharkiv. Vol. 29 (33). P. 232-238. 